\title{
A Teoria dos Ciclos Termais
}

( RESUMO)

\author{
AULA INAUGURAL DE 1950 - PROFERIDA PELO \\ PROF. E. A. SALGADO
}

Iniciando a aula, mostra o Prof. Salgado a distribuição geográfica dos grandes derrames de rochas básicas do globo, inclusive daquele que se conhece, no Brasil, constituindo a "província magmática do Brasil meridional".

Cogitando da origem de tais derrames, penetra um tanto no domínio da seísmologia, que lhe fornece dados a respeito da constituição das zonas menos superficiais do planeta.

Com desenhos e esquemas adequados faz consideraçöes meticulosas acêrca da localização, sob os oceanos e os continentes, do chamado "substrato basáltico".

Passando a outra ordem de considerações, estuda a radioatividade de minerais que ocorrem em diferentes tipos de rochas, cogitando da desintegração radioativa do urânio, do tório e do potássio. 
Levando em conta o calor latente de fusão do basalto, o calor gerado pela desintegração dos elementos radioativos e a concentração provável dêstes no "substrato basáltico" põe em evidência, através de cálculo muito simples, a possibilidade de que o "substrato basáltico" se funda a intervalos de trinta milhões de anos, aproximadamente, gerando um magma primordial que seria a fonte de outros magmas, dêle derivados por adequados mecanismos de diferenciação.

Como a teoria da fusão cíclica do "substrato" precisa de ser posta à prova, em fase dos diferentes fatos geológicos que integram os quadros da geologia clássica, o Prof. Salgado procura, agora, verificar se há um perfeito paralelismo entre a bela teoria de Joly e os marcos mais relevantes da história geológica.

Explica como se pode determinar a idade das rochas eruptivas por meio dos "relógios radioativos", isto é, das diferentes substâncias radioativas que nelas aparecem.

Passa a fazer considerações sôbre as "revoluções geológicas" que o globo tem sofrido e sôbre a divisão da história geológica em eras e períodos.

Para finalizar, lançando mão de um quadro comparativo do Professor Holmes, põe em destaque a notável concordância entre os dados fornecidos pela teoria dos ciclos termais de Joly e os dados apresentados pelos "relógios radioativos", no que diz respeito à idade das diferentes formações geológicas, desde o pré-cambriano até os nossos dias. 